\title{
AMENDMENTS
}

\section{Author Correction: Expert assessment of future vulnerability of the global peatland carbon sink}

J. Loisel(D, A. V. Gallego-Sala (D), M. J. Amesbury (D), G. Magnan, G. Anshari, D. W. Beilman (D), J. C. Benavides, J. Blewett (D), P. Camill, D. J. Charman (D), S. Chawchai (D), A. Hedgpeth, T. Kleinen D, A. Korhola, D. Large, C. A. Mansilla D , J. Müller (iD, S. van Bellen, J. B. West (D) Z. Yu, J. L. Bubier, M. Garneau, T. Moore, A. B. K. Sannel ID, S. Page, M. Väliranta (D), M. Bechtold (D), V. Brovkin (D), L. E. S. Cole (iD, J. P. Chanton, T. R. Christensen (D), M. A. Davies (D), F. De Vleeschouwer, S. A. Finkelstein, S. Frolking, M. Gałka, L. Gandois (D), N. Girkin (D) L. I. Harris (D), A. Heinemeyer (D), A. M. Hoyt D, M. C. Jones (D), F. Joos (D), S. Juutinen, K. Kaiser, T. Lacourse (D), M. Lamentowicz $\mathbb{D}$, T. Larmola (D), J. Leifeld (D), A. Lohila, A. M. Milner D, K. Minkkinen, P. Moss (D, B. D. A. Naafs (D), J. Nichols D, J. O'Donnell, R. Payne, M. Philben, S. Piilo iD, A. Quillet, A. S. Ratnayake D, T. P. Roland, S. Sjögersten, O. Sonnentag (D), G. T. Swindles, W. Swinnen, J. Talbot (D), C. Treat (D), A. C. Valach (D) and J. Wu iD

Correction to: Nature Climate Change https://doi.org/10.1038/s41558-020-00944-0, published online 7 December 2020.

In the version of this Analysis originally published, the following affiliation for A. Lohila was missing: 'Finnish Meteorological Institute, Climate System Research, Helsinki, Finland'. This affiliation has now been added, and subsequent affiliations renumbered accordingly, in the online versions of the Analysis.

Published online: 21 January 2021

https://doi.org/10.1038/s41558-021-00991-1

(c) The Author(s), under exclusive licence to Springer Nature Limited 2021

\section{Author Correction: Climate change impacts on renewable energy supply \\ David E. H. J. Gernaat (D), Harmen Sytze de Boer (D), Vassilis Daioglou (D), Seleshi G. Yalew (D), Christoph Müller (1) and Detlef P. van Vuuren (1) \\ Correction to: Nature Climate Change https://doi.org/10.1038/s41558-020-00949-9, published online 11 January 2021.}

In the version of this Article originally published, the colours in the scale bars in Figs. 1c and 2, Extended Data Figs. 2c and 4, and Supplementary Figs. $2 \mathrm{c}$ and 4 were inadvertently flipped such that they were shown as being blue to red, from left to right, but should have been red to blue. The online versions of the Article have been corrected and the Supplementary Information file has been replaced. The tick marks and values have not changed.

Published online: 18 February 2021

https://doi.org/10.1038/s41558-021-01005-w

(C) The Author(s), under exclusive licence to Springer Nature Limited 2021 